\title{
Snooping Handicraft-Ecotourism in Lombok
}

\author{
Hengky, S. H. \\ Universitas Bina Darma, Prasetiya Mandiri, Indonesia \\ Tel: 62-896-5704-5738_E-mail: hengky_halim@yahoo.com.au
}

Received: Dec. 19, 2017 Accepted: Jan. 2, 2018 Published: Jan. 7, 2018

doi:10.5296/bmh.v6i1.12623 URL: http://dx.doi.org/10.5296/bmh.v6i1.12623

\begin{abstract}
Handicraft ecotourism has not become a leading sector in Lombok. Recently, the President of Indonesia has targeted to improve the performance of this sector to be ten times over the next four years. Factually, obstacles encountered with the development of handicrafts in Lombok include raw materials, facilities, and weakness in material, design, creativity, and promotion. This study addressed a theme of a sustainability, economy and development of a region. Determining the performance gap between the existing and expected, would inform them about the priority over their program. This study found four (4) points that get to improve: Firstly, the Ministry of Tourism will prioritize training for the artisans in making the new design of the new craft actively. Secondly, develop innovative and developing creative new designs and themes from crafts, adapting lessons to the needs of travelers and meeting their criteria. Thirdly, the artisans expand their distribution area to improve its business by coordinating, strengthening the standardization of craft quality. Finally, they get to substitute the material without changing the function and culture of local handicrafts.
\end{abstract}

Keywords: Economy, Handicraft-ecotourism, Sustainability, Training, Creative, Innovative-design, Substitute-material 


\section{Introduction}

In the next two years, President of Indonesia has targeted international tourist arrivals to 20 million and domestic tourists has increased from 250 million to 275 million. So far, the handicraft tourism sector has not become a leading sector. Moreover, the Ministry of Tourism supports tourism programs were released the Indonesia World of Wonderful. It started by tidying Tourism Central Lombok, West Nusa Tenggara. He ranged from the Northern side, the middle of the South, aim to attract tourists and the welfare of society by developing the potential for the region (Palupi, 2015).

\subsection{Introduce the Problem}

Factually, obstacles encountered with the development of handicrafts in Lombok include raw materials, facilities, and weakness in marketing. Consequently, it has an impact on the artisans, especially the young generation. In addition, the lack of public awareness that tourism can generate high returns. However, awareness of tourism as a leading sector not well ordered, and no special attention from the government to restructure institutions in supporting this effort (Palupi, 2015; IrmanBima, 2015).

Craft is one of the supporting tourism in West Nusa-Tenggara that has various kinds of craft produced among other wooden crafts with furniture and carving, craft wicker, bamboo, pearl, ceramics, and so forth. Craft art is spread throughout the territory of Lombok has a style and distinctive characteristics such as woven Kethak, Cukli ornaments, and finishing of natural materials (Ufig, 2015).

The other craft is the art of ceramics / pottery. This craft spread almost throughout the region, West Lombok, Central Lombok and East Lombok. West Lombok concentrated on Banyumulek Village areas, in the middle Penujak Lombok and East Lombok in Masbagik. Previously, ceramic was traditional crafts that produced as fulfilling the needs of the household. Artisans made the ceramic from generation of generation. It originally did by women. They only work on ceramic items to make-ends purposes, as a complement to the kitchen and ceremonial needs, but a clay pot that serves to cook placed above the Jangkin (Angelo), pitcher, Genthong, and others (Rahardjo, 2013).

Selection of a Handicraft Ecotourism (HE) material is good for basic craft materials. This material can produce a wide range of the products. Comprehensive efforts made to improve the potential for sustainable handicraft production of environmentally friendly materials. Its production process does form an environmentally friendly byproduct covering various other handicraft products and its proper disposal (Debnath, 2017, 2015; Hengky, 2014a).

The Ministry of Labor stated that it took effort to strengthen entrepreneurship in supporting tourism in Lombok handicrafts. It is planned and to be made in coordination with the Ministry of Tourism and Creative Economics Agency (Hardum, 2015; Kamarudin \& Sajilan, 2013). Therefore, it needs the observations to give the feedback or information about the gap between the existing and expected performance of handicraft ecotourism in supporting the decision on both institutions. This research is responding to the Indonesian President's target and Tourism Ministry's program by snooping handicraft ecotourism in Lombok, Indonesia. 


\subsection{Explore Importance of Handicraft Ecotourism}

\subsubsection{Ecotourism}

Ecotourism has many benefits of supporting the economic development of handicrafts in remote areas. Ecotourism helps support livelihoods and boost the economies of coastal communities in the region. In addition, it had very low market entry barriers and minimized environmental impact (Das \& Chatterjee, 2015; Riasi \& Pourmiri, 2016). Among the different ecotourism subcategories, it has the potential for realistic growth due to its natural characteristics of crafts (Riasi \& Pourmiri, 2016).

Ecotourism proven to maintain the environment naturally by increasing environmental conservation efforts. In addition, such activities increase the economic contribution to the local community through the environmental management of natural environment. The utilization of natural and environmental resources from these activities, is accompanied by programs reducing environmental impacts due to HE (Anup, 2017; Gilbert 2003; Hengky, 2017; Hornoiu, 2017).

\subsubsection{Handicraft Ecotourism}

From basic materials of different natural craft, obtained or taken from plants. Some important aspects of this handicraft production and its market potential. Some basic materials of natural handicraft ecotourism (HE) material is some important ingredients to support sustainable handicraft business. Furthermore, the use of such materials in craft with the concept of ecotourism (Debnath, 2017; Riasi \& Pourmiri, 2016; Hengky, 2014b).

Rural craft activity became an economic activity through a labour-intensive program that received greater attention. The way it works has the potential for the development of rural handicraft producers groups. Developing rural handicrafts affected the cultural-environmental changes and policies for rural handicraft producers in terms of gaining provincial and local development support. Against this background, the growth of HE presents the findings that rural handicraft companies are in the form of small and medium-sized SMEs related to natural tourism, corporate economy, artisans groups, and designers (Bull \& Willard, 1993; Bygrave, 1989; Bhawe, Gupta, \& Jain, 2006; Chittithaworn, Islam, Keawchana, \& Yusuf, 2001; Della-Giusta, \& Phillips, 2006; Rogerson, 2013; Shane \& Venkataraman, 2000).

Handicraft activities greatly affect the lives of local people and siding with their economic development in support of their lives. These craft production activities cause a positive economic impact on improving their welfare. The access to HE is relevant to help the poverty. It reduced promotion agenda with community-based economic development (Ashley, Boyd, \& Goodwin, 2000; Ochanda, 2015; Scarlat, 2014; Shapero \& Sokol, 1982).

The development of ecotourism handicraft and environmental conservation efforts often accompanied by training activities by establishing the division of tasks to indigenous peoples with various activities related to their economic development. The training providers tend to view local participation as an indicator of the success of the HE program. This combined tendency contributes to the economy of local communities. Capability improvement training 
seen as a form of middle ground between the social wishes of local communities (Jain, 2009; Mentore, 2017; Yenn, 2013).

A number of natural materials are available in nature from plants, animals, insects, and minerals. Every fiber is different from the others, and it causes its difference in character. Thus, the material used in the design and development of handicraft products. This handicraft industry, regardless of the newer design and utilize this naturally material use for sustainable growth (Debnath, 2016; Okorie, Kwa, Olusunle, Akinyanmi, \& Momoh, 2014).

The development of HE management done by collecting independent community base of an empowerment program. It done by designing craft with the creativity of cultural development, empowering local artisans based on their natural culture and controlling the development of its design. In addition, it also built economic contribution to supporting local people life by educating the artisans in utilizing original culture and characteristic of natural area. However, the activity also accompanied by efforts to reduce negative impact on environmental and maintained the authenticity of its culture (Anup, 2017; Utomo, Hamdani, Riyanto, \& Awatara, 2017).

\section{Method}

This one-year study conducted in Lombok from October 2014 to November 2015. The data was collected purposive, stratified sampling. Base of the tabulation of content analysis of 270 respondents, which consists: Staff of the ministry of tourism and creative economy, Department of Transportation and the Department of Trade. The other respondent: Tour operator, Travel agents and the artisan crafts; Front office's officers; Taxi and Bus drivers; Local community and tourists. Each respondent was questioned three different times for the consistency other judgment (Jennings, 2001).

All questionnaires were distributed purposively by employing 20 students, which about empowering local community by designing the craft creatively (Urban \& Barreira, 2007; Chen, Parker, \& Lin, 2006; Wong, 2001), and controlled and developed natural culture (Gielen, Hoeve, \& Nieuwenhuis, 2003; Mark, 1993). Besides, building economics contribution (Goel \& Karri, 2006), and utilizing original culture (Mendoza-Ramíreza \& Toledo-López, 2014; Ramakrishna, 2014; Belwal, Tamiru, \& Singh, 2012). However, it reduced negative impact, and maintaining HE cultured (Anup, 2017; Utomo, Hamdani, Riyanto, \& Awatara, 2017).

The collected data was tabulated by using a content analysis (Cho \& Lee, 2014; Gottschalk, 2013; Ello \& Kyngas, 2008; Riffe, Lacy, \& Fico, 1998; Hsieh \& Shannon, 2005; Cohen, 1960), based on HE (Urban \& Barreira, 2007; Chen et al., 2006; Wong, 2001): Exploratory analysis of its parameters; Posting each parameter of HE; Frequency counted of HE; and Result and discussions. $\mathrm{K}=$ Kappa value $>0.6=$ significant, and $\mathrm{K}<0.6=$ poor (Cho \& Lee, 2014; Gottschalk, 2013; Riffe et al., 1998; Hsieh \& Shannon, 2005; Cohen, 1960).

\section{Results}

Based on the entrepreneurial orientation, this study explores the existing performance of HE 
in Lombok (Table 1) which was shown to be less significant $(\mathrm{K}=0.5814)$. The indicator was expressed by the weak development of the economic contribution to HE (0.1401) and safe-guarding the HE culture (0.1529). In addition, there are still indications of weak efforts to reduce negative environmental impacts (0.1656) and control of natural cultural development (0.1720). However, local community empowerment dominates in designing and creating creative craft $(0.1911)$.

Table 1. Existing of the handicraft ecotourism in Lombok

\begin{tabular}{|l|l|l|}
\hline Attributes & Value & \% Freq \\
\hline Empowering local community by designing the craft creatively & 30 & 0.1911 \\
\hline Controlled and developed natural culture & 27 & 0.1720 \\
\hline Building economics contribution & 22 & 0.1401 \\
\hline Utilizing original culture & 28 & 0.1783 \\
\hline Reduced negative impact & 26 & 0.1656 \\
\hline Maintaining HE cultured & 24 & 0.1529 \\
\hline K= Kappa Value $=0.5814$ & & \\
\hline
\end{tabular}

Furthermore, expected HE's performance in Lombok (Table 2) shown by the Kappa value (K $=0.7296)$. Natural cultural control and development are the main thing (0.1827). This can be made by strengthening community empowerment in creative HE designed (0.1777) with the use of indigenous culture (0.1675). In addition, local economic development strengthened (0.1624), accompanied by efforts to reduce negative environmental impacts due to $\mathrm{HE}$ activities. However, developing HE activity still needs to maintain by preserving the $\mathrm{HE}$ culture (0.1523).

Table 2. Expected-handicraft ecotourism in Lombok

\begin{tabular}{|l|l|l|}
\hline Attributes & Value & \% Freq \\
\hline Empowering local community by designing the craft creatively & 35 & 0.1777 \\
\hline Controlled and developed natural culture & 36 & 0.1827 \\
\hline Building economics contribution & 32 & 0.1624 \\
\hline Utilizing original culture & 33 & 0.1675 \\
\hline Reduced negative impact & 31 & 0.1574 \\
\hline Maintaining HE cultured & 30 & 0.1523 \\
\hline K= Kappa Value $=0.7296$ & & \\
\hline
\end{tabular}

However, performance gaps analysis indicated that there is a wide gap (Table 3 ) between the existing (Table 1) and expected (Table 2). In terms of Kappa coefficient, there was some distance away $(0.1482$ or $25.5 \%)$. It was necessary to strengthen the control and development 
of natural culture (0.0108) and development of economic contribution to the local community (0.0223). The analytical gap tabulation also shows that it was necessary to adapt the local community empowerment program in designing HE creatively $(-0.0134)$ because of natural cultural utilization $(-0.0108)$. In addition, attention should be paid more to controlling the negative environmental impacts and conservation of the culture $(-0.0006)$.

Table 3. Gap analysis of expected and existing performance of HE

\begin{tabular}{|l|l|l|l|}
\hline Attributes & \% Freq & \% Freq & Gap \\
\hline Empowering local community - designing a craft creatively & 0.1911 & 0.1777 & -0.0134 \\
\hline Controlled and developed natural culture & 0.1720 & 0.1827 & 0.0108 \\
\hline Building economics contribution & 0.1401 & 0.1624 & 0.0223 \\
\hline Utilizing original culture & 0.1783 & 0.1675 & -0.0108 \\
\hline Reduced negative impact & 0.1656 & 0.1574 & -0.0082 \\
\hline Maintaining HE cultured & 0.1529 & 0.1523 & -0.0006 \\
\hline K= Kappa Value & 0.5814 & 0.7296 & 0.1482 \\
\hline
\end{tabular}

The above disparity occurs and there are some problems such as existing problems of environmental hygiene, roads, curbing buildings on the beach. As for the problem of $\mathrm{HE}$ is raw materials, training, and selling price. Moreover, the problem of coastal renditions and cleanliness along Gili Trawangan. This location became the tourism business that tourists expect the local government clean up the former material that was still abandoned post-control of coastal buildings immediately.

\section{Discussion}

Referred to disparity performance, this study discussed the problem of waste in Lombok. It currently overcome by the Waste Bintang Sejahtera Bank program that was establish in July 2010 with the aim at finding solutions to waste problems (Elena, 2017). Their goals are to develop local entrepreneurship, community empowerment and local government support to manage waste and the environment. This project was a community-based waste management program. Currently there are 55 units of Trash Bank managed by Lombok in Waste Bank Bintang Sejahtera. They continue to encourage and support others to start their own Bank Trash Unit. The organization also provides training intensively for how to process organic and inorganic waste. They also conduct business incubation workshops and train them through the process. This support mean ensuring the Garbage Bank Unit was well operated and benefited as a return value of the effort to preserve the environment.

In addition, one of the improvement on the means of ring roads included drainage canals in Gili Trawangan can be settling down that during the rainy season. In addition, waste management should also be controlling professionally. This is important to clean it up immediately to overcome the problem of waste that has been critical of Gili Trawangan.

The limitation of materials becomes an important issue in HE. According to these artisans, 
the demand for such goods was very high, both from within the region and from Bali. The searchers of these materials often banned or even arrested by the guard, when they were looked for raw materials in the forest. In addition, they also need the attention on relevant agencies to solve the problem. They need to get training for the artisan and help the capital.

They revealed the price of goods or webbing Ketak that has been so low. While, the price of staple households increasingly rising so many artisans that have not made craft Ketak. There is also a constraint on the artisans and collectors in the village Peresak Karang Bayan (Kardin \& Zoecky, 2017).

Handicraft trade produced from Balinese bamboo materials to export markets is now very slow and less conducive. Likewise, scarce material increasingly. While, the material is difficult to obtain and in substitution with interesting bamboo from Java and Lombok. Australian businesspersons. There are still some that ask for it. Bamboo crafts formed by drawing or designing but in limited quantities at an agreed price. The problem of handicrafts Export from Bali is slowly justified from the Head of Foreign Trade, Industry and Industry Bali.

Based on the above problems, this study shown that artisans need to be more proactive responded the trend of tourists taste. In addition, it needs creations from them to create $\mathrm{HE}$ with different materials, and different types of finishing from handicrafts. Nevertheless, it needs standardization required handicraft products. This will adjust the needs, expectations and tourist trends. In terms of craft materials, there are Ketak, Clay, Cukli, and Yarn. Recently, this study discussed about four (4) crafts would thrive on Lombok:

Firstly, the province of West Nusa Tenggara, which is famous as agricultural area and has a variety of flourishing-plants. One of the basic ingredients of the craft is a plant called "Ketak" by local people who are in Latin called "Lygodium Circinatun." These plants include ferns that run on the parent plant or anyway. Currently the material is one of the raw materials of making various forms of crafts through the process of drying, division and formulation. Raw materials, in addition to having high artistic value is also not free from everyday use. Narmada people that use it as a tool of knitting artisans in everyday life.

In development until 2011, the "Ketak" weaving craft is found in 3 (three) districts in West Lombok, Central Lombok and East Lombok, with 64 centers, Business Unit 15004 units and can accommodate 25631 workers and absorb investment of USD 1.116 million (Afifi, 2015). While, the raw material is abundant there. In 1988 the government of Weaving "Ketak", which was first developed around 1986 in the village of Nyurbaya Gawah Narmada Barat, started training and intensive skills training, design development, local and national exhibitions, that this wicker product can be expanding on the West of East Lombok.

"Ketak" is one of craft that marketed by an Art Shop in Nusa Tenggara Barat and Bali tourism area. It also attaches to the function of the product, the weave is usually using as a decorative item. This craft is not only the domestic market but also to penetrate foreign market countries such as Germany, England, France and Asia as well as in some other developing countries. Both exporters-importers in Lombok and from other regions 
participate actively in the sale of handicrafts abroad or domestic handicraft, which makes the demand for raw materials increased significantly.

Secondly, other handicraft materials are clay made for pottery. This craft has its own uniqueness, so do not be surprised if sometimes more expensive. There are three famous pottery-producing villages in Lombok, call it Banyumulek in West Lombok, Central Lombok and Penujak in Penakak in East Lombok, each with unmatched and distinctive characteristics (Fauzia, 2015).

Banyumulek pottery is a unique handicraft from West Nusa Tenggara used as a tool that is marketed namely Kendi Maling. Some villages produce handicrafts for generations such as the famous Banyumulek village in the pottery village, the village is famous for its traditional Sukarare woven cloth and the famous Labuapi village with its carvings. One of the best-selling pottery is a typical West Nusa Tenggara craft that inherited from a long time in the form of a round plate that serves as a clay player to make pottery (Raharjo, 2013).

Pottery, better known as "Pottery", became one of the works and at the same time established the tradition of ancestral ancestors, and retained as the skills of locals that famous for the world. Generally, pottery used to store rice, salt and spices other than for cooking purposes. Pottery making is the work of a mother and daughter, if not selling and bringing to the market is the duty of father and son, but with the progress of time so fast that most father and son take part in making pottery work together to get maximum results and good quality (Afifi, 2015).

From above mentioned, it needs standardization required to produce and create simple pottery and did not easy about a people to think about its requirements (Afifi, 2015; Fauzia, 2015; Rahardjo, 2013; Sejati, 2015). It is complicated and divided:

a. Clay searches processed

A careful examination needs to get the best clay according to the quality standard. The good clay do not have to come from a pottery village but comes from a nearby village. Clay does not have to use it directly to take deep accuracy and ensures that the clay was not mixing with rocks and small soil.

\section{b. Drying process}

After examination, the clay is cut like a cube and shines in the sun, it takes about three (3) or four (4) days. The piece of stone dried. It has ground into a soft flour dough and stored before use as a dough. The most interesting thing to watch without the modern tools needed to support the making of pottery. The clay layer added to the amount of the original dough. While, sawmill rotated the object / tool used to form the desired object. The shape is finished that does not yet finish. There are also artisans specially assigned to be decorating after objects / pots that allowed drying in place that is not too much sun.

c. Varnish process of coconut oil

A vinyl vase is a combination of coconut oil and left to dry before scraped / rubbed with 
black stone or other traditional tools. The surface dried in the sun and looks shiny. It takes a day or even rubbed to smooth in the afternoon to add fragrance.

\section{d. Burning process}

Goods / pots that ready burnt and collected into an open oven covered by rice straw. It burnt for more than four (4) hours and the surrounding production temperature $400-800^{\circ} \mathrm{C}$.

\section{e. Coloring}

The last task is to choose the right color, if desired garnet granules coated into acidic liquids as desired color, and just snap the husk.

Thirdly, Cukli's crafts from Rungkang, it is the outer surface of handicrafts adorned with various pieces of pearl shells attached to various types of wooden handicrafts. They can form many motifs, such as the design of flora and fauna or various types of primitive ornaments. Initially, Rungkang villagers only make cooking utensils and household appliances that vary. The resulting product is less salable. Therefore, eventually they started looking for antiques' Sasak legacy such as ceramics, unique boxes and daggers. This will increase its demand by creating a new proactive design craft (Yustitia, 2013).

Since 1989, efforts residents started had made it. Until now, the market demand for the crafts not only from within the country. It also slowly began to enter overseas markets. Today, it embedded items are no longer confined to the box, but also various other furniture items such as cabinets, dressers and wall hangings. Various types of the souvenirs such as ashtrays candies go on sale in the market. In addition, the collection of antiques such as masks or sculptures are not separate from the decor it either.

Therefore the beauty emitted, the ancient box had given a touch of ornament "Cukli," pieces of pearl shells attached to wooden boxes or wooden crafts. Patch motifs range from flora, fauna, to primitive ornaments. Businessperson from Bali is relentlessly requesting supplied them to overseas markets, which are slowly forming. Since then, the face to the village turned into a pot manufacturer in the village of artisans. A rowing arts shop is standing along the Rungkang Bowl road. In the village, this craft provides job opportunities for young people in Kampung Rungkang and brings many blessings to the community too. To find out how the results are, its good stop by the house residents. Almost every home produces these crafts. The process begins with cutting pearl shells, making motifs on wooden handicrafts, putting shells on wooden crafts, sand, cauldrons, varnished, and painted. Repairing colored and painted by developing a new design proactively will increase the demand for tourists to buy it as well.

Finally, West Nusa Tenggara Province has various handicrafts. Some of the attractions that are relied upon to support the activities of handicraft tourism in this region, among others, Sukarara Village as the center of handicraft weaving in the village of Bleke. Among them, there is a woven-typical of West Nusa Tenggara. The woven fabric known as "Songket" is the hallmark of Lombok Island. It is a woven fabric made by adding clothing threads, ornaments made by inserting a silver, gold or colored thread on a warp thread. Sometimes, there 
decorated with beads, shells or coins too. In addition, it well knows now, there are ways to make fabrics in an elegant way (Wahyuni, 2015; Perbatasari, 2012; Saputra, 2015).

Classic woven fabrics ranging from yarn making and dye making to traditional yarn making by using swirling weights with fingers. Ballasts are shaped like the tops made of wood or terra cotta. Preparation of materials other than cotton yarn, can also bark, banana fiber, pineapple fiber, palm leaves and dyes consisting of two colors, blue and red. The color is obtained from indigo or Mirinda Citrifonela or Noni. There are also dyes from other plants, such as dark red. Motives vary: there are chicken motifs, eight florals, four flower motifs and many other designs. Based on traditional culture, creating many new designs will increase its demand as well.

\section{Conclusions}

Based on this discussion, this study found there is a slightly widened gap between current and expected performance of artisans. Therefore, they can actively increase to create a new competitive designs, new materials and finishing handicrafts to respond to presidential targets. Moreover, the Ministry of Tourism develops a workshop program to match the needs of tourism strengthening and the Ministry of Manpower plan (Yenn, 2013). In short, there are four (4) points that need to be to fix in the near future:

Firstly, the Ministry of Tourism will prioritize training for the artisans in making the new design of the new craft actively. It trains them in creating new craft designs with different raw materials. In addition, the Minister of Tourism improves information on design and refreshed handicraft materials by promoting handicrafts on social gathering and promotion on social media sites. These efforts strengthen local government funding to support and sustain their promotion of environmental care (Jain, 2009; Mentore, 2017).

Secondly, develop innovative business by creating new business methods of craft and exciting new learning in teamwork by developing creative new designs and themes from crafts, adapting lessons to the needs of travelers and meeting their criteria (Mendoza-Ramíreza \& Toledo-López, 2014).

Thirdly, the artisans can create new business to achieve competitive position, and expand the craft distribution area to improve its business by coordinating, strengthening the standardization of craft quality (Utomo et al., 2017).

Finally, crafts artisans can use substitution materials without changing the function and culture of local handicrafts to sustain and meeting the demand and expectations of tourists about the design, coloring, and quality of handicrafts.

\section{Implications}

In terms of materials, the Ministry of Tourism prepares and develops training for the artisans in utilizing substitution materials by reducing negative environmental impacts. The workshop trained them to make crafts with various natural materials and new designs. In addition, the Minister can accommodate the tourism trends by responding to expectations, handicrafts, and promoting traditional craft programs (Hardun, 2015). 
Artisans can adapt to creating craft designs by exploring traditional skills and rural activities. They can produce new designs and a variety of materials that are easily obtainable to sustain it. They can make it with other presentations - expressions of quality standardization based on the concept of cultural heritage.

\section{Acknowledgement}

The author would like to thank SHINE Institute for helping to distribute the questionnaires to the respondents. In this good opportunity, the author would like to thank the editors and anonymous reviewers who have supported in the process of publication of this journal.

\section{References}

Anup, K. C. (2017). Ecotourism in Nepal. The Gaze: Journal of Tourism and Hospitality, 8, $1-19$.

https://www.nepjol.info/index.php/GAZE/article/download/17827/14472

Ashley, C., Boyd, C., \& Goodwin, H. (2000). Pro-poor tourism: putting poverty at the heart of the tourism agenda. Natural Resources Perpective, 51, 1-6. [Online] Available: http://dlc.dlib.indiana.edu/dlc/bitstream/handle/10535/4134/51-pro-poor-tourism.pdf?sequenc $\mathrm{e}=1$

Belwal, R., Tamiru, M., \& Singh, G. (2012). Microfinance and sustained economic improvement: Women small-scale entrepreneurs in Ethiopia. Journal of International Development, 24(1), 84-99. https://doi.org/10.1002/jid.1782

Bhawe, N., Gupta, V. K., \& Jain, T. K. (2006). The Entrepreneurship of the Good Samaritan: A Development Framework to Understand Social Entrepreneurship Using Insights from Qualitative Study. Social Science Research Network, 1-40. https://doi.org/10.2139/ssrn.902685

Bull, I., \& Willard, G. E. (1993). Towards a theory of entrepreneurship. Journal of Business Venturing, 8(3), 183-195. https://doi.org/10.1016/0883-9026(93)90026-2

Bygrave, W. B. (1989). The Entrepreneurship Paradigm (I): A Philosophical Look at its Research Methodologies. Entrepreneurship Theory and Practice, 14(1), 7-26. [Online] Available: $\mathrm{http}: / /$ ssrn.com/abstract $=1505870$

Chen, J. C. H., Parker, L. J., \& Lin, B. (2006). Technopreneurship in Native American businesses: current issues and future with a case study. International Journal of Management and Enterprise Development, 3(1-2). https://doi.org/10.1504/IJMED.2006.008243

Chittithaworn, C., Islam, M. A., Keawchana, T., \& Yusuf, D. H. M. (2001). Factors Affecting Business Success of Small \& Medium Enterprises (SMEs) in Thailand. Asian Social Science, 7(5), 180-190. https://doi.org/10.5539/ass.v7n5p180

Cho, J. Y., \& Lee, E. (2014). Reducing Confusion about Grounded Theory and Qualitative Content Analysis: Similarities and Differences. The Qualitative Report, 19(64), 1-20. [Online] Available: http://www.nova.edu/ssss/QR/QR19/cho64.pdf 


\section{Macrothink}

Business and Management Horizons

ISSN 2326-0297

2018, Vol. 6, No. 1

Cohen, J. (1960). A Coefficient of Agreement for Nominal Scales. Educational and Psychological, 20, 37-46. https://doi.org/10.1177/001316446002000104

Das, M., \& Chatterjee, B. (2015). Ecotourism: A panacea or a predicament? Tourism Management Perspectives, 14, 3-16. https://doi.org/10.1016/j.tmp.2015.01.002

Debnath, S. (2015). Great Potential of Stinging Nettle for Sustainable Textile and Fashion. In Handbook of Sustainable Luxury Textiles and Fashion, 43-57. Springer Singapore. https://doi.org/10.1007/978-981-287-633-1_3

Debnath, S. (2016). Natural Fibres for Sustainable Development in Fashion Industry. In Sustainable Fibres for Fashion Industry, 89-108. Springer Singapore. https://doi.org/10.1007/978-981-10-0522-0_4

Debnath, S. (2017). Sustainable production of bast fibres. In Sustainable Fibres and Textiles, 69-85. https://doi.org/10.1016/B978-0-08-102041-8.00003-2

Della-Giusta, M., \& Phillips, C. (2006). Women entrepreneurs in the Gambia: challenges and opportunities. Journal of International Development, 18(8), 1051-1064. https://doi.org/10.1002/jid.1279

Elena. (2017). Inspiring, Sabah Bintang Sabah Bintang Trash Bank UID-UNSDSN Award. Tribunenews.

http://www.tribunnews.com/nasional/2017/11/02/menginspirasi-bank-sampah-bintang-sejahte ra-sabet-uid-unsdsn-award

Ello, S., \& Kyngas, H. (2008). The qualitative content analysis process. Journal of Advanced Nursing, 62(1), 107-115. https://doi.org/10.1111/j.1365-2648.2007.04569.x

Fauzia, Y. (2015). Shopping and Learning to Make Pottery at Sentra Pottery of East Lombok, Hello Lombok. [Online] Available: http://hellolombokku.com/belanja-dan-belajar-membuat-tembikar-di-sentra-gerabah-lomboktimur/

Gielen, P. M., Hoeve, A., \& Nieuwenhuis, L. F. M. (2003). Learning Entrepreneurs: Learning and Innovation in Small Companies. European Educational Research Journal, 2(1), 90-106. https://doi.org/10.2304/eerj.2003.2.1.13

Gilbert, R. J. (2003). Ecotourism and education for sustainability: A critical approach. International Review for Environmental Strategies, 4(1), 75-83. [Online] Available: https://espace.library.uq.edu.au/view/UQ:121262

Goel, S., \& Karri, R. (2006). Entrepreneurs, Effectual Logic, and Over-Trust. Entrepreneurship Theory and Practice, 30(4), 477-493. https://doi.org/10.1111/j.1540-6520.2006.00131.x

Gottschalk, L. A. (2013). Content Analysis of Verbal Behavior: New Findings and Clinical Applications (pp. 19-22). London, New York: Routledge.

Hardum, S. E. (2015). The Employment Ministry Training Center Navigates for Creative 
Industries.

Beritasatu.com.

[Online]

Available:

http://www.beritasatu.com/ekonomi/297238-kemnaker-arahkan-blk-ke-industr i-kreatif.html

Hengky, S. H. (2014a). Beneficial images: Batik handicraft tourism in Yogyakarta. Indonesia. Business and Economic Research, 5(1), 11-23. http://dx.doi.org/10.5296/ber.v5i1.6760

Hengky, S. H. (2014b). Image Analysis: Performance Gaps of Batik Craft in Yogyakarta, Indonesia. Business Management and Strategy, 5(2), 125-138. https://doi.org/10.5296/bms.v5i2.6766

Hengky, S. H. (2017). Presiding Ora Coastal Ecotourism in Maluku, Indonesia. Business Management and Strategy, 8(2), 27-44. https://doi.org/10.5296/bms.v8i2.11827

Hornoiu, R. I. (2017). Analysis of the Romanian Students studying Tourism Preferences regarding the Goods and Services Eco-sustainable offered by an Ecotourism Destination. Calitatea, 18(158), 103.

Hsieh, H., \& Shannon, S. E. (2005). Three Approaches to Qualitative Content Analysis. Qualitative Health Research, 15(9), 1277-1288. http://dx.doi.org/10.1177/1049732305276687https://doi.org/10.1177/1049732305276687

IrmanBima. (2015). Economic, District Government Bima. [Online] Available: http://bimakab.go.id/pages-ekonomi.html

Jain, T. K. (2009). Discovering Social Entrepreneurship, Asia-Pacific Journal of Management Research and Innovation, 5(1), 21-34. https://doi.org/10.1177/097324700900500103

Jennings, G. (2001). Tourism Research (pp. 136-152). John Wiley \& Sons Australia, Ltd.

Kamarudin, H. S., \& Sajilan, S. (2013). Critical Success Factors of Technopreneurship in the Creative Industries: A Study of Animation Ventures. Review of Integrative Business and Economics Research, 2(1), 1-37. [Online] Available: $\mathrm{http}: / /$ search.proquest.com/openview/dbfc7a1 afc3e4550e6657e832c05ccb3/1?pq-origsite $=$ gsc holar

Kardin \& Zoecky. (2017). Artisan Woven Material Difficulty, Office of Communications, Informatics and Statistics. [Online] Available: http://diskominfo.lombokbaratkab.go.id/pwngerajin-anyaman-ketak-kesulitan-bahan/

Mark, E. (1993). Innovation as the craft of combination: Perspectives on technology and economy in the spirit of Schumpeter. Dissertation, Linköping University, The Tema Institute, Technology and Social Change. Linköping University, Faculty of Arts and Sciences, 209.

Mendoza-Ramíreza, L., \& Toledo-López, A. (2014). Strategic orientation in handicraft subsistence businesses in Oaxaca, Mexico. Journal of Marketing Management, 30(5-6), 476-500. http://dx.doi.org/10.1080/0267257X.2014.893248

Mentore, L. (2017). The virtualism of "capacity building” workshops in indigenous Amazonia: Ethnography in the new middle ground. HAU: Journal of Ethnographic Theory, 7(2), 279-307. https://doi.org/10.14318/hau7.2.028 


\section{I Macrothink}

Business and Management Horizons

ISSN 2326-0297

2018, Vol. 6, No. 1

Ochanda, M. M. (2015). Effect of financial deepening on growth of small and medium-sized enterprises in Kenya: A case of Nairobi County. Research Journal of Finance and Accounting, 6(10), 141-155.

Okorie, N. N., Kwa, D. Y., Olusunle, S. O. O., Akinyanmi, A. O., \& Momoh, I. M. (2014). Technopreneurship: An Urgent Need in the Material World for Sustainability in Nigeria. European Scientific Journal, 10(30), 59-73. [Online] Available: http://eujournal.org/index.php/esj/article/view/4441

Palupi, W. T. (2015). Arief Yahya, Minister of Tourism of RI: We will prepare typical Tourism, Republika. Business Talk. [Online] Available: http://www.republika.co.id/berita/koran/bincang-bisnis/15/01/26/nirw55-arief-yahya-menteripariwisata-ri-kita-akan-siapkan-wisata-khas

Perbatasari, H. (2012). Let's! Learning to Weave Songket Village Sukarara. Detiktravel.com. [Online] Available: http://ravel.detik.com/read/2012/03/09/170000/1862481/1025/yuk-belajar-menenun-songket -di-desa-sukarara

Raharjo, T. (2013). West Nusa Tenggara Lombok ceramics, art craft Indonesia. [Online] Available:

http://kasonganartvillage.blogspot.co.id/2013/03/keramik-lombok-nusa-tenggara-barat.html

Ramakrishna, K. (2014). Rural Entrepreneurship through Micro Finance, Bank Lending and Subsidy in Karnataka. Journal Entrepreneurship \& Organization Management, 3(2). https://doi.org/10.4172/2169-026X.1000113

Riasi, A., \& Pourmiri, S. (2016). Examples of Unsustainable Tourism in Middle East. Environmental Management and Sustainable Development, 5(1), 69-85. https://doi.org/10.5296/emsd.v5i1.8705

Riffe, D., Lacy, S., \& Fico, F. (1998). Analyzing Media Massage: Using quantitative content analysis research (3rd ed., pp. 18-71). London, New York: Routledge. [Online] Available: https:/www.amazon.com/Analyzing-Media-Messages-Quantitative-COMMUNICATION/dp/ 0805852980

Rogerson, C. M. (2013). Tourism, small firm development and empowerment in post-apartheid South Africa. Small Firms in Tourism, 13-29.

Saputra, R. (2015). Tourist island of Lombok Indonesia, Exploring Destinations in West Nusa Tenggara. Restroomrevelations. [Online] Available: http://restroomrevelations.blogspot.co.id/2015/07/Wisata-Pulau-Lombok-Indonesia-Menjelaj ahi-Destinasi-Terpopuler-di-Nusa-Tenggara-Barat.html

Scarlat, C. (2014). Technopreneurship-An Emerging Concept. Faima Business \& Management Journal, 2(3), 5-13.

Sejati, I. K. (2015). Travel Banyumulek pottery in Lombok, wisata.com directory. [Online] Available: http://direktori-wisata.com/wisata-kerajinan-tembikar-di-banyumulek-lombok/ 


\section{Macrothink}

Business and Management Horizons

ISSN 2326-0297

2018, Vol. 6, No. 1

Shane, S., \& Venkataraman, S. (2000). The Promise of Entrepreneurship as a Field of Research. The Academy of Management Review, 25(1), 217-226. https://doi.org/10.5465/AMR.2000.2791611

Shapero, A., \& Sokol, L. (1982). The Social Dimensions of Entrepreneurship. Encyclopedia of Entrepreneurship, l, 72-90. [Online] Available: http://ssrn.com/abstract=1497759

Ufig. (2015). Souvenirs typical of Lombok. Everybody should be happy. [Online] Available: http://www.fangirlslogic.com/2015/07/smart-shopping-oleh-oleh-khas-lombok.html

Urban, B., \& Barreira, J. (2007). Insights into technopreneurship: self-employment perceptions among engineering students. South African Journal of Higher Education, 21(5), 567-583.

Utomo, A., Hamdani, A., Riyanto, R., \& Awatara, I. G. P. D. (2017). Redesigning Independent Community Empowerment Model for Household Craftsmen. Sebelas Maret Business Review, 1(2). https://doi.org/10.20961/smbr.v1i2.11436

Wahyuni, T. (2015). Know the Types and beauty of Lombok Traditional Cloth. CNN Indonesia. [Online] Available: http:/www.cnnindonesia.com/gaya-hidup/20150130142740-277-28541/mengenal-macam-da n-keindahan-kain-tradisional-lombok/

Wong, P. K. (2001). Utilizing multinational companies, fostering Technopreneurship: the changing role of $\mathrm{S} \& \mathrm{~T}$ policies in Singapore. International Journal of Technology Management, 22(5-6). https://doi.org/10.1504/IJTM.2001.002977

Yenn, W. Y. (2013). Evaluation of technopreneurship policies in Singapore. Dissertation, School of Humanities and Social Sciences, Nanyang Technological University.

Yustitia. (2013). Crafts bought Cukli in Kampung Rungkang, Wisata Lombok tiada taranya. [Online] Available: http://lombok.panduanwisata.id/oleh-oleh/memborong-kerajinan-cukli-di-kampung-rungkang

\section{Copyright Disclaimer}

Copyright for this article is retained by the author(s), with first publication rights granted to the journal.

This is an open-access article distributed under the terms and conditions of the Creative Commons Attribution license (http://creativecommons.org/licenses/by/3.0/). 